\title{
Nephrotic Range Proteinuria
}

National Cancer Institute

\section{Source}

National Cancer Institute. Nephrotic Range Proteinuria. NCI Thesaurus. Code C123066.

In children, urine protein greater than or equal to $40 \mathrm{mg} / \mathrm{m}^{\wedge} 2 / \mathrm{h}$; alternatively, greater than or equal to $0.25 \mathrm{~g} \mathrm{~m} / \mathrm{mmol}$ creatinine or $2 \mathrm{gm} / \mathrm{gm}$ creatinine obtained from a first morning specimen. 